\title{
北海道における新築戸建て住宅の断熱および設備仕様調査 \\ 一次エネルギー消費量の推定と設備の選択要因に関する考察 \\ THERMAL INSULATION AND EQUIPMENT PERFORMANCE \\ OF A NEWLY BUILT DETACHED HOUSE IN HOKKAIDO
}

Estimation of primary energy consumption and selection factors for house equipment

\author{
立松宏一 ${ }^{*}$, 廣田誠一 ${ }^{* *}$, 高倉政寛 ${ }^{* *}$, 月館 司 ${ }^{* * *}$ \\ 鈴木大隆***, 羽山広文**** \\ Koichi TATEMATSU, Tomohito HIROTA, Masahiro TAKAKURA, \\ Tsukasa TSUKIDATE, Hirotaka SUZUKI and Hirofumi HAYAMA
}

\begin{abstract}
The thermal performance and equipment type specified for a newly built house were investigated as benchmarks to enable the selection of appropriate insulation and equipment specifications.

The prevalence of electric heater installations for space heating and hot water supply decreased in 2012, compared to 2011. However, it is estimated that the primary energy consumption is high in particularly cold areas of Hokkaido, because this type of equipment remains common in these areas. Because there is an initiative to contractors when the equipment type is determined, it is important to provide appropriate information to these contractors.
\end{abstract}

Keywords : Questionnaire Survey, Heating Installation, Hot-water Apparatus, Energy-saving Standard, Primary Energy, Cost 実態調査, 外皮平均熱貫流率, 暖房, 給湯, 省エネルギー基淮, コスト

\section{1.はじめに}

住宅の省エネルギー性能は断熱および設備の仕様によって大きく 左右される。従来の住宅の省エネルギー基準 ${ }^{1)}$ は、適合義務基準で はないものの、断熱性能に関する判断基準になってきた。また、北 海道においては、道の民間住宅施策として推進してきた「北方型住 宅」において、2010 年に熱損失係数 $\mathrm{Q} \leqq 1.3 \mathrm{~W} /\left(\mathrm{m}^{2} \mathrm{~K}\right)$ （換気熱回収 は算定上含めない）を一要件とする「北方型住宅 $\mathrm{ECO} 」$ を設定、さ らに札幌市では 2012 年に創設した「札幌版次世代住宅基準」で Q $\leqq 0.5 \mathrm{~W} /\left(\mathrm{m}^{2} \mathrm{~K}\right)$ の等級を設けるなどの誘導施策もあり、従来の住宅の 省エネルギー基準に比べて断熱性能が極めて高い住宅の建設も一部 で進んでいる。

住宅設備については、石油およびガスを熱源とした潜熱回収型機 器や電気ヒートポンプ式の機器が普及するなど、熱効率の向上が進 んでいる。また、北海道においては、1990 年制定の北方型住宅基準 において集中暖房を原則とするなど 2)、住宅の耐久性や居住環境向 上の観点からセントラルヒーティングの普及を推進してきており、 暖房・給湯の方式や熱源種別は多様化している。換気設備について も 2003 年のシックハウス対策の義務化を契機として、様々な機器 が市場展開されている。
この間、2008 年をピークとする燃料価格高騰により、暖房・給湯 設備の電化が進んだ。その際、蓄熱暖房器、電気式パネルヒーター、 電気温水器など電気ヒーター式の機器が多く採用されたことから、 住宅の熱損失が小さくなりつつも、一次エネルギー消費量が増加し ていることが問題となった ${ }^{3)}$ 。その後、2011 年の東日本大震災を契 機に、北海道では 2012 年夏から節電要請が実施され、熱源として の電気に対する意識は再び変化している。

このような中、2009 年 1 月告示の住宅事業建築主の判断基準 4) では、住宅の省エネルギー性能が断熱・遮熱性能のみではなく、暖 房、冷房、換気、照明、給湯の各設備が消費する年間の一次エネル ギー消費量として規定され、2013 年改正の住宅・建築物の省エネル ギー基準 5)では、この考え方がすべての住宅に拡大された。

以上のように、現在は住宅の省エネルギーに関わる情勢が目まぐ るしく変わる移行期にあると言える。したがって、エネルギーに関 する政策目標、既存のエネルギー供給システム、ユーザーのニーズ などとの整合を図りながら、適切な断熱・設備仕様の選択を行うこ とができるよう誘導を行っていく必要があり、そのためには、住宅 の断熱・設備仕様の現状や選択要因を把握し、今後の方向性を検討 することが必要である。

\footnotetext{
本論文は，参考文献25）の内容に新たな調査結果と考察を加えて加筆し，まとめたものである。

* 北海道立総合研究機構北方建築総合研究所 工修

** 北海道立総合研究機構北方建築総合研究所

$* * *$ 北海道立総合研究機構北方建築総合研究所 博士 (工学)

**** 北海道大学大学院工学研究院 教授 - 博士 (工学)

Hokkaido Research Organization Northern Regional Building Research Institute, M. Eng. Hokkaido Research Organization Northern Regional Building Research Institute

Hokkaido Research Organization Northern Regional Building Research Institute, Dr. Eng. Prof., Faculty of Eng., Hokkaido Univ., Dr. Eng.
} 
既往の資料として、断熱仕様については、住宅金融支援機構の住 宅仕様実態調查報告 6)や断熱材出荷統計を利用した断熱水準の推定 事例 7)がある。住宅設備についても業界団体による出荷統計 8),99や、 インターネットによるアンケート調查事例 10)がある。また、既存統 計資料の分析により、灯油、ガス、電力の消費構成には明確な地域 性があることがわかっている 11),12)。しかしながら、一般住宅を対象 に建設地や事業者属性を明らかにした調查は行われておらず、年々 変化していると考えられる住宅の断熱・設備仕様や、北海道内にお けるエネルギー消費量の地域性までは把握することができていない。 特にエネルギー消費量への影響が大きい住宅設備の選択要因につ いては、エンドユーザーを対象としたアンケートによる調査事例 13) があるものの、誘導を図る観点では、住宅建設事業者と建築主のど ちらに選択の主導権があるのかという点での実態把握も必要と考え られる。

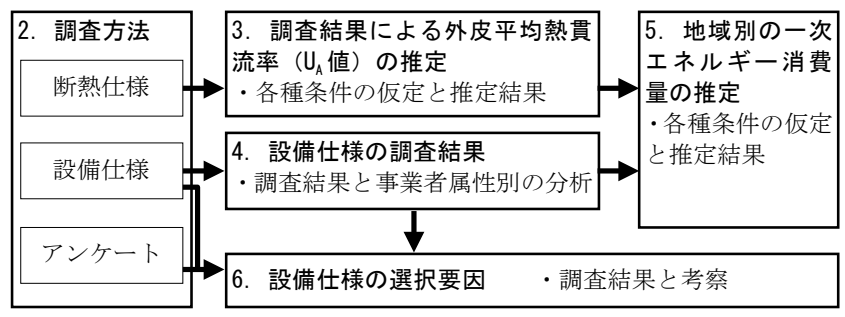

図 1 調査内容と本文の各項目の関係
そこで本研究では、住宅の断熱・設備仕様の現状や、選択要因を 把握することを目的に、道内に建設された新築戸建て住宅を対象と した実態調査を行った。さらに、一次エネルギー消費量を推計する とともに、特に一次エネルギー消費量への影響が大きい、暖房・給 湯設備の選択要因に関する考察を行ったので報告する。

図 1 に調查内容と本文の各項目の関係を示す。外皮平均熱貫流率 （以下、「 $\mathrm{U}_{\mathrm{A}}$ 值」という）と一次エネルギー消費量の推定は、建物 形状など各種仮定に基づくため、仮定した条件はそれぞれ該当する 項目（3.と5.) で示している。

\section{2. 調査方法}

\section{1 調査対象}

調査は 2010 年から 2012 年に新築された木造戸建て住宅を対象と して 3 か年にわたり実施した。このうち、本報では 2012 年の新築 住宅を主な分析対象とし、一部動態把握のため、2011 年新築住宅の データも扱う。なお 2010 年と 2011 年新築住宅の調查結果は既報 14),15)にとりまとめている。

\section{2 調査票の配布及び回収方法}

調査は、住宅建設事業者に調査票を郵送して実施した。調查票の 送付先は、(株) 北海道住宅通信社の「北海道住宅データバンク」を 参考に、各年に戸建住宅で 1 棟以上の建築確認を受けた全事業者と し、当該事業者が 1 年間に建設した住宅についてまとめて回答を求 めた。

\begin{tabular}{|c|c|c|c|c|c|}
\hline 会社名 & & (市町村名 & ) & \multirow{2}{*}{ 平成 24年 (1月 1 12月) の新築戸建住宅施工総数 } & \multirow{2}{*}{$(\quad)$ 棟 (※S造、 $\mathrm{RC}$ 造を除く $)$} \\
\hline 連絡先 & 担当者 & （電話 & ) & & \\
\hline
\end{tabular}

\section{壁·屋根·天井·床·基碤の断熱材の番号表}

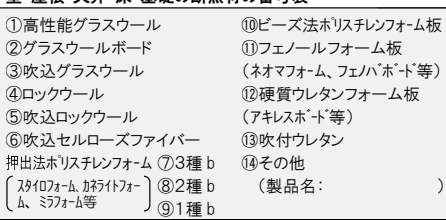

\section{窓の仕様の番号表}

(樹脂または木枠 普通ペアガラス

2)樹脂または木枠 Low-Eペアガラスガス無し

3樹脂または木枠 Low-Eペアガラス Ar または Kr r ガス封入

(4)樹脂または木枠 Low-Eトリプルガラス Ar または $\mathrm{Kr}$ ガスス封入

(5)その他

\section{暖房設備の番号表}

(1)温水暖房(石油)

(10VIVIDO·ECO ONE

3温水暖房(電気ヒートポンプ）（11エコウイル

(4)温水暖房(ガス(従来型)）（12)エコジョーズーコレモ

5)温水暖房(ガズエコジョーズ)）、(13灯油ストーブ

6)ヒートポンプ式セントラル空調

8)電気式パネルヒーター

\section{給湯設備の番号表}

(1)゙ス瞬間式(従来型) (6)電気温水器

(2)ガス瞬間式(エコジョーズ) (7)エコキュート

3)石油瞬間賗湯式时暖房と同し

(4)石油瞬間式(従来型) (9)その他(

5)石油瞬間式(エコフィール)

\section{換気設備の番号表}

(1)多外式(第 1 種） 6壁付十同時给排气型フフン

(2)タタ卜式(第 1 種熱交換あり) (熱交換あり)

(2) タ外式(第 1 種熱交換あり) ( 熱交換あり)

(3)斥外式(第 2 種)

(5)壁付十同時給圤气型フアン

(7)壁付け給気型フアン

(9)その他(

\section{1. 断熱仕様}

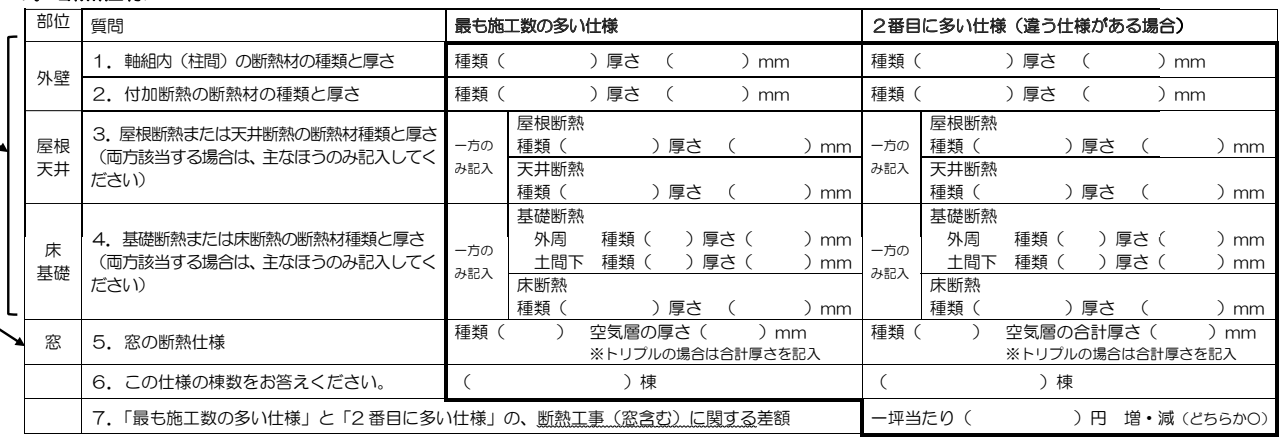

\section{2. 設備仕様}

\begin{tabular}{|l|l|l|}
\hline 種類 & 質問 & 最も施工数の多い仕标 \\
\hline
\end{tabular}

- 暖房 1. 暖房設備の種類 (住戸内で複数種類の暖房

給晹機を設置している場合は複数回答可)

給湯 2. 給湯設備の種類

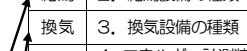

計涆 4. エネルギー計測装置 (HEMS、見える化装置)

種類 ( ) 棟数 ( 棟 種類

種類 ( ) 棟数 ( ) 棟 種類

種類 $(\quad) \quad$ 棟数 $(2)$ 棟

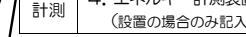

3. アンケート

（1）外壁の断熱仕様として、コストを报きにして、お客さんにおすすめしたい仕様をお答えください。

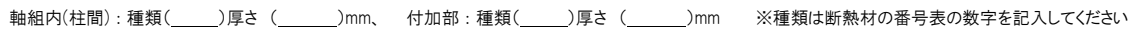

（2）設備 (暖房・給湯) の種類は主に誰が提案していますか（1つだけ○をつけてください） (1)施工業者が提案する（2どちらかというと施工業者が提案する（3どちらかというとお客さんが提案する（4)お客さんが提案する

（3）暖房設備と給湯設備のどちらの種類が先に決まりますか（1つだけ○をつけてください） (1)暖房設備がはじめに決まる（2)給湯設備がはじめに決まる（3)同時に決まる

（4）設備（暖房・給湯）の種類が最終的に決まる要因は何ですか（もっともあてはまる番号に1つだけ○をつけてください） (1)設備価格·施エコス卜（2)燃料代·電気代（3)設備業者の関係（4)安定性·メンテナンスのしやすさ 
調查票の回収は、同封した返信用封筒による郵送または FAX に より行った。締め切りまでに返送がなかった事業者に対しては、電 話または FAXにより再依頼を行った。

\section{3 調査項目}

2012 年新築住宅の調査に用いた調査票を図 2 に示す。回答率向 上のためには極力回答者の負担とならない調査内容とする必要があ るため、断熱性能については各部位の断熱材種別と断熱厚さのみ調 査した。設備仕様は省エネルギー基準上の分類を参考に選択肢を設

\section{表 1 有効回答数}

(a)事業者数

\begin{tabular}{|c|c|c|c|c|}
\hline \multicolumn{2}{|l|}{ 建設年 } & 対象事業者数 & 回答事業者数 & 回答率 \\
\hline 2011年 & & 1,748 & 572 & $33 \%$ \\
\hline 2012年 & & 1,709 & 506 & $30 \%$ \\
\hline $\begin{array}{l}\text { 年間建 } \\
\text { 設棟数 } \\
\text { 別内訳 }\end{array}$ & $\begin{array}{c}1 \text { 棟 } \\
3 \text { 棟以下 } \\
10 \text { 棟以下 } \\
50 \text { 棟以下 } \\
51 \text { 棟以上 }\end{array}$ & $\begin{array}{c}740 \\
448 \\
310 \\
175 \\
36 \\
\end{array}$ & $\begin{array}{c}142 \\
130 \\
133 \\
77 \\
24 \\
\end{array}$ & $\begin{array}{l}19 \% \\
29 \% \\
43 \% \\
44 \% \\
67 \% \\
\end{array}$ \\
\hline
\end{tabular}

(b)棟数

\begin{tabular}{|c|c|c|c|c|}
\hline \multicolumn{2}{|l|}{ 建設年 } & 対象棟数 & 回答棟数 & 回答率 \\
\hline \multicolumn{2}{|l|}{ 2011年 } & 12,316 & 6,870 & $56 \%$ \\
\hline \multicolumn{2}{|l|}{ 2012年 } & 12,366 & 7,254 & $59 \%$ \\
\hline $\begin{array}{l}\text { 事業者 } \\
\text { 所在地 } \\
\text { 別内訳 }\end{array}$ & $\begin{array}{c}\text { 大規模事業者 } \\
\text { 空知・石狩・後志 } \\
\text { 胆振・日高 } \\
\text { 渡島・桧山 } \\
\text { 上川・留萌・宗谷 } \\
\text { オホーツク } \\
\text { 十勝 } \\
\text { 釧路・根室 } \\
\text { 道外 }\end{array}$ & $\begin{array}{c}1,902 \\
5,614 \\
886 \\
744 \\
1,254 \\
534 \\
915 \\
482 \\
35\end{array}$ & $\begin{array}{c}1,925 \\
2,841 \\
472 \\
239 \\
740 \\
310 \\
548 \\
176 \\
3\end{array}$ & $\begin{array}{c}100 \% \\
51 \% \\
53 \% \\
32 \% \\
59 \% \\
58 \% \\
60 \% \\
37 \% \\
9 \% \\
\end{array}$ \\
\hline
\end{tabular}

(c)第 1 仕様と第 2 仕様

\begin{tabular}{l|cc|cc|cc}
\hline \multirow{2}{*}{2012 年 } & \multicolumn{2}{|c|}{ 第1仕様 } & \multicolumn{2}{|c|}{ 第2仕様 } & \multicolumn{2}{|c}{ 計 } \\
\cline { 2 - 8 } & 回答社数 & 棟数 & 回答社数 & 棟数 & 回答仕様数 & 棟数 \\
\hline 断熱仕様 & 506 & 6,507 & 173 & 747 & 679 & 7,254 \\
暖房設備 & 506 & 5,490 & 237 & 1,447 & 743 & 6,937 \\
給湯設備 & 500 & 5,551 & 217 & 1,372 & 717 & 6,923 \\
換気設備 & 485 & 6,176 & 134 & 759 & 619 & 6,935 \\
\hline
\end{tabular}

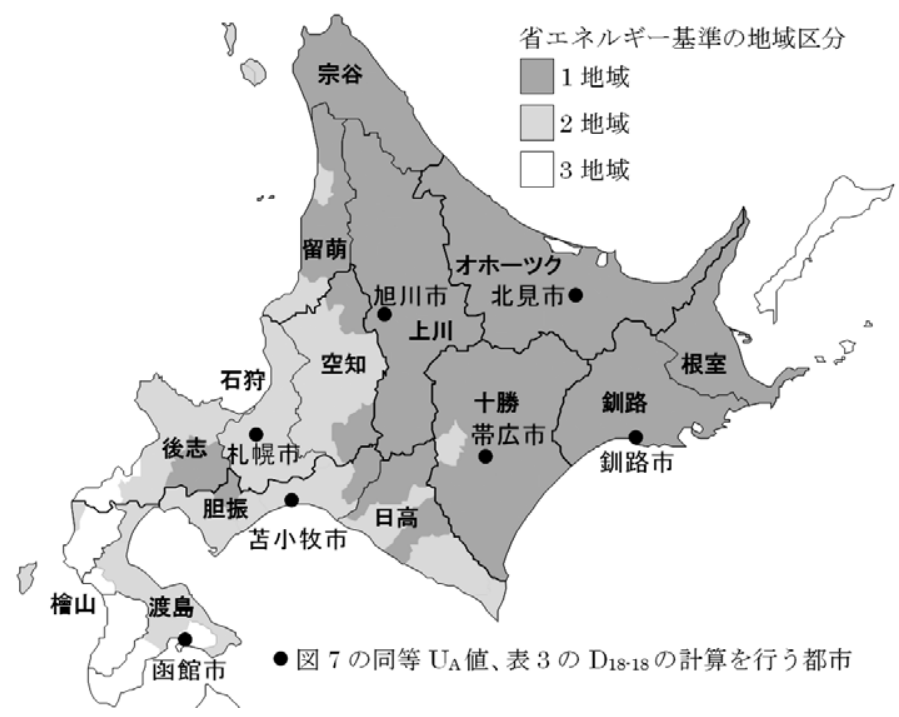

図 3 振興局の位置と省エネルギー基準の地域区分
けた。また、1 事業者で複数の仕様を有する場合は、施工棟数の多 い順に 2 仕様（以下、順に「第 1 仕様」「第 2 仕様」という）を調 査することとし (2011 年新築住宅については 3 仕様まで調查)、そ れぞれの仕様を把握した。なお、断熱仕様と設備仕様の組み合わせ および設備仕様相互の組み合わせは関連付けせずに、断熱仕様と各 設備仕様のそれぞれ第 1 仕様と第 2 仕様の建設棟数を調査した。さ らに、アンケートとして設備の選択要因に関する質問を設けた (2012 年新築住宅の調查のみ)。

\section{4 回答事業者の属性}

表 1 に調査対象件数と有効回答数を示す。返送された調査票には 一部の回答が久落しているものがあったが、各部位の断熱仕様がも れなく把握できる場合を有効回答として扱った。事業者数の集計(表 1(a)）には、事業者の年間建設棟数別（建築確認申請棟数に基づく） の内訳を示している。棟数の集計（表 1(b)）には事業者所在地別の 内訳を示している。事業者所在地は本社または北海道内における代 表営業拠点所在地（各社 1 か所）により振興局別に分類した。「道 外」に分類されているのは、北海道内に営業拠点を持たない事業者 である。参考に図 3 に振興局と省エネルギー基準の地域区分を示す。 また、回答のあった事業者のうち建設棟数の上位 5 社は建設地が北 海道全域にわたるため、事業者所在地別の集計では「大規模事業者」 として別枠で扱う。対象棟数は建築確認申請がなされた住宅につい て計上しているが、回答棟数には建築確認不要の住宅も含まれてい る。なお、対象棟数 12,366 棟に対し、同期間の建築確認不要の住 宅も含む国土交通省の住宅着工統計による新築戸建て住宅棟数は 13,940 棟である。表 1 (c)には第 1 仕様と第 2 仕様の回答数を示す。 各調查項目とも、第 1 仕様の棟数が 8〜9 割を占めている。すなわ ち、事業者ごとに建設する住宅の代表的な断熱・設備仕様を有して いることになる。

\section{3. 調査結果による外皮平均熱貫流率 $\left(\mathrm{U}_{\mathrm{A}}\right.$ 値) の推定 \\ 3.1 各種条件の仮定と $U_{A}$ 值の推定方法}

調查により得られた各部位の断熱仕様から、 $\mathrm{U}_{\mathrm{A}}$ 值を推定する方法 を以下に述べる。

断熱材の熱伝導率は文献 ${ }^{16)}$ に掲載されている值を用いる。複数の 規格がある断熱材の場合は、最も一般的に使用されていると考えら れる規格の熱伝導率を採用寸る (具体的な值は既報 ${ }^{14}$ に記載) 注 1 )。 図 4 に各部位の熱貫流率を算定するための断面構成を示す。熱橋面 積比率は構法により 異なるが、文献 16)を参考に木造軸組工法を想定 して設定する注 2)。道内では天井は吹込み工法が多く、外壁の付加部 は下地を用いない工法が多い実態から、天井と外壁付加断熱部には 熱橋が生じないものとする。基礎断熱の場合は、すべて床下空間を 有し、躯体の外側で断熱されていると想定する。サッシの熱貫流率 は建具とガラスの仕様に応じ、文献 ${ }^{16)}$ に掲載されている值を用いる。 玄関ドアの熱貫流率は $2.33 \mathrm{~W} /\left(\mathrm{m}^{2} \mathrm{~K}\right)$ とする。

各部位の面積などは、図 5 に示す北方型住宅 157 件注3)の実デー 夕を用い、各断熱仕椂に対し 157 通りで $\mathrm{U}_{\mathrm{A}}$ 值を計算する。

\section{$3.2 U_{A}$ 值の推定結果}

以上に述べた各部位の断面構成や面積の仮定に基づき推定した $\mathrm{U}_{\mathrm{A}}$ 值の相対度数分布を図 6 に示す。相対度数は、棟数の割合として 求めている（以降、5.までは同様に棟数で集計を行う）。参考に 


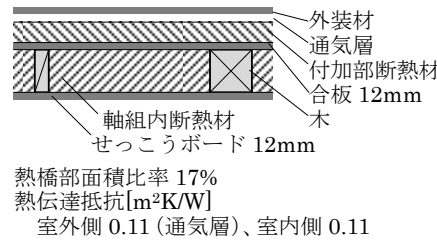

(a)外壁

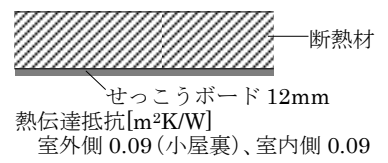

(c)天井

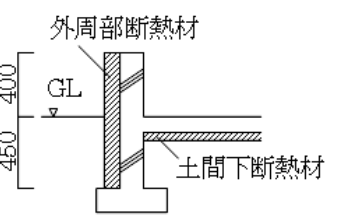

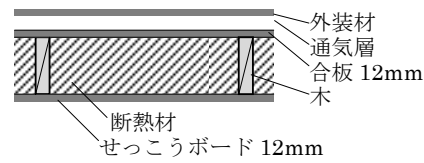

熱橋部面積比率 $14 \%$ 熱伝達抵抗 $\left[\mathrm{m}^{2} \mathrm{~K} / \mathrm{W}\right]$ 室外側 0.09 (通気層)、室内側 0.09

(b) 屋根

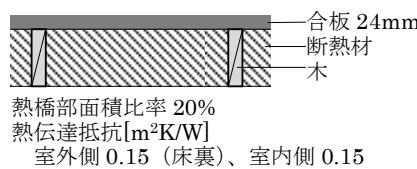

(d) 床

基礎の熱貫流率 $U_{\mathrm{F}, \mathrm{j}}(\mathrm{W} /(\mathrm{mK}))$ の計算式 $\mathrm{U}_{\mathrm{F}, \mathrm{j}}=1.80-1.36\left(0.85 \mathrm{R}_{\mathrm{w}}\right)^{0.15}$ $-0.01\left(6.14-\mathrm{R}_{\mathrm{w}}\right)\left(\left(0.5 \mathrm{R}_{\mathrm{f}}\right) 0.9\right) 0.5$

ただし、 $\mathrm{U}_{\mathrm{F}, \mathrm{j}} \geqq 0.05$

$\mathrm{R}_{\mathrm{w}}$ : 外周部断熱材の熱抵抗 $\left[\mathrm{m}^{2} \mathrm{~K} / \mathrm{W}\right]$ $\mathrm{R}_{\mathrm{f}}$ : 土間下断熱材の熱抵抗 $\left[\mathrm{m}^{2} \mathrm{~K} / \mathrm{W}\right]$

(e) 基礎

図 4 各部位の熱貫流率算出上の断面構成

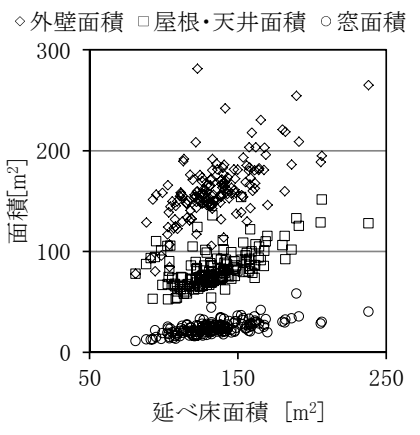

(a)外壁、屋根・天井、空の面積

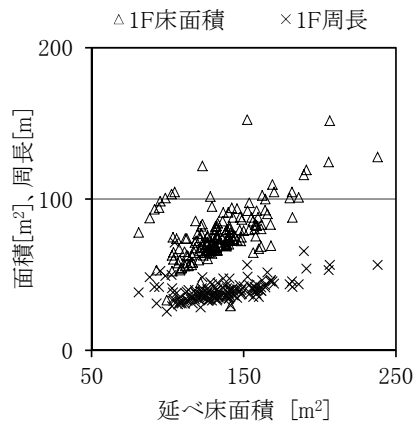

(b) $1 \mathrm{~F}$ 床面積、 $1 \mathrm{~F}$ 周長
図 $5 U_{A}$ 値の推定に用いる各部位の面積・周長（実住宅 157 件）

2011 年の調査結果を併せて示すが、平均值では差がなかった。また、 住宅の省エネルギー基準で規定されている $\mathrm{U}_{\mathrm{A}}$ 值基準（1、2 地域 $\mathrm{U}_{\mathrm{A}} \leqq 0.46 \mathrm{~W} /\left(\mathrm{m}^{2} \mathrm{~K}\right) 、 3$ 地域 $\left.\mathrm{U}_{\mathrm{A}} \leqq 0.56 \mathrm{~W} /\left(\mathrm{m}^{2} \mathrm{~K}\right)\right)$ を満たす割合は 1 、 2、3 地域それぞれ $89 \% 、 90 \% 、 99 \%$ となった。

図 7 に建設事業者の規模（年間建設棟数）別と所在地別の推定 $\mathrm{U}_{\mathrm{A}}$ 值を示す。平均值は棟数による加重平均で算出している。また、 当該カテゴリーとその他のカテゴリーで母平均の差の検定注 ${ }^{4)}$ を行 い、有意水準 0.01 または 0.05 で有意差があったカテゴリーに**、* を付している。

事業者規模別（図 7(a)）では、建設棟数の少ない事業者で $\mathrm{U}_{\mathrm{A}}$ 值 のばらつきがやや大きく、平均值は年間建設棟数 4 棟〜 50 棟の事業 者がやや小さい（断熱性能が高い）傾向がある。

事業者所在值別のグラフ（図 7(b)）には、札幌市を含む空知・石 狩・後志の平均 $\mathrm{U}_{\mathrm{A}}$ 值と暖房負荷が同等となる各地域の $\mathrm{U}_{\mathrm{A}}$ 值を併せ て示す。暖房負荷計算には室内取得熱を考慮したデグリーデー法 ${ }^{17}$ ) を用い、デグリーデーや日射量は 2000 年版の標準年 EA 気象デー タ18)をもとにした文献值 19 )を用いた。計算地点は各地域で人口が最 大の都市（図 3 に示している都市）、その他の条件は表 2 に示すと おりとした。平均 $\mathrm{U}_{\mathrm{A}}$ 值には地域差が見られるが、上川・留萌・宗
谷、オホーツク、釧路・根室の各地域では、気候の違いによる暖房 負荷の差を埋め合わせるほどの断熱性能の違いはないことがわかる。 ただしパッシブソーラーなどの手法により暖房負荷の差を解消して いる住宅もあるかもしれないが、 $\mathrm{U}_{\mathrm{A}}$ 值推定の際の仮定では建物形状 の地域差を考慮していないため、今回の分析では反映されていない。

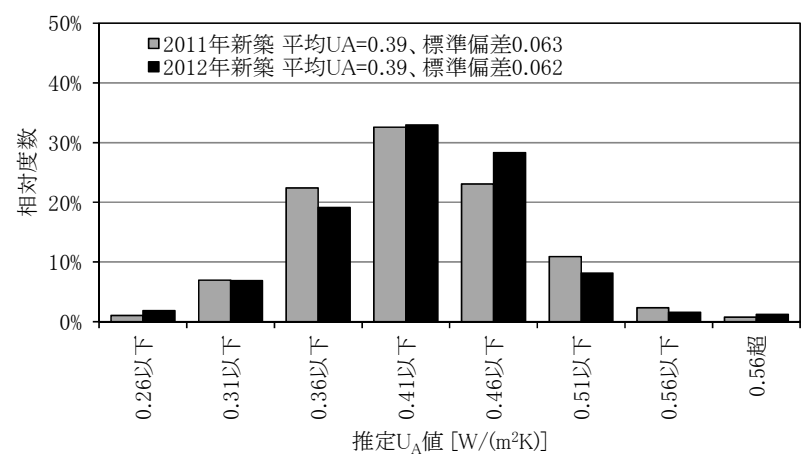

図 6 推定した $U_{A}$ 值の度数分布（棟数割合）

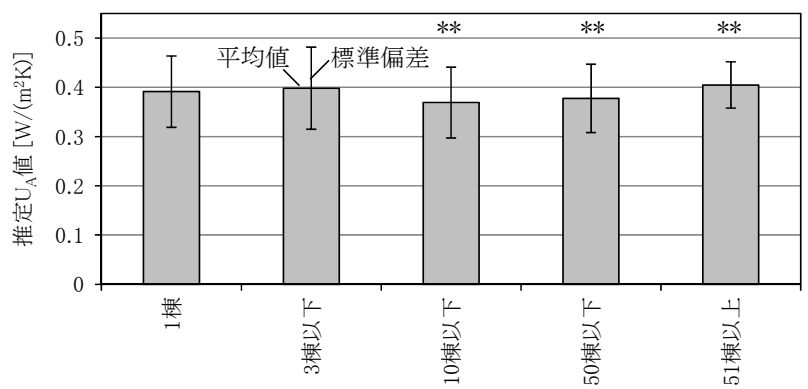

(a)事業者規模（年間建設棟数）別

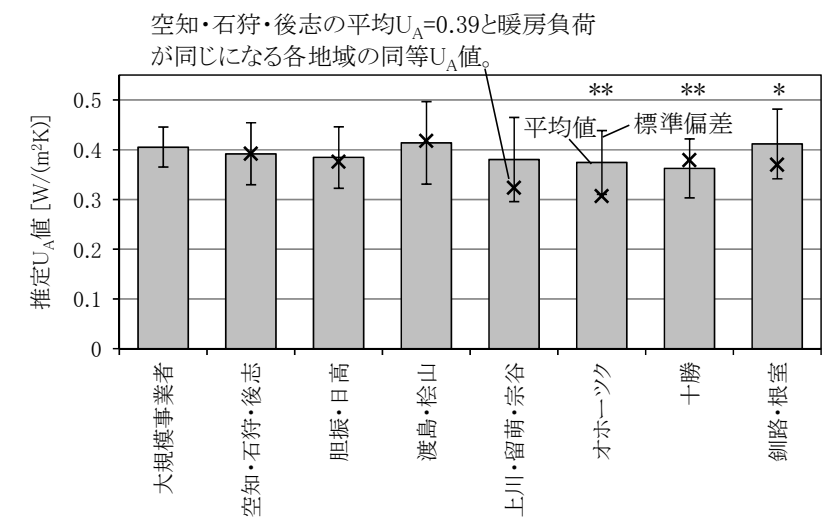

(b)事業者所在地別

** : $\mathrm{p}<0.01 、 *: \mathrm{p}<0.05$

図 7 カテゴリー別の推定 $U_{A}$ 值

表 2 図 7 の同等 $U_{A}$ 值の計算に用いた各係数

\begin{tabular}{|c|c|c|}
\hline 項目 & 值 & 根拠 \\
\hline 外皮面積 $\left[\mathrm{m}^{2}\right]$ & 347 & \multirow{4}{*}{ 図5に示寸住宅の平均值 } \\
\hline 換気対象容積 $\left[\mathrm{m}^{3}\right]$ & 324 & \\
\hline 空面積(南面) [m²] & 11.6 & \\
\hline 空面積(東西面計) $\left[\mathrm{m}^{2}\right]$ & 8.9 & \\
\hline 暖房期の空の日射熱取得率 & 0.33 & $\begin{array}{l}\text { Low-E複層ガラス (日射取得型)の日射熱取得 } \\
\text { 率 } 0.64 \times \text { 取得日射量補正係数 } 0.51\end{array}$ \\
\hline 室内発生熱[W] & 621 & $\begin{array}{l}\text { 文献3)による調理・照明ほかの実測値に人体 } \\
\text { 発熱 } 120 W(4 \text { 人、在室率 } 0.5 を \text { 想定)を加算 } \\
\end{array}$ \\
\hline 室温設定 $\left[{ }^{\circ} \mathrm{C}\right]$ & 21.7 & \begin{tabular}{|l} 
文献3)による12月〜2月の居間および主寝室 \\
実測值の平均值
\end{tabular} \\
\hline
\end{tabular}




\section{4. 設備仕様の調査結果}

\section{1 使用設備の内訳}

図 8 に設備仕様の調查結果を示す。 2011 年新築と 2012 年新築住 宅の採用設備を比較すると、電気ヒーター式熱源機の温水暖房、電 気蓄熱暖房器、電気式パネルヒーター、電気ヒーター温水器といっ た電気ヒーター式の機器の減少が顕著である。一方、潜熱回収型の ガス機器が大きく増加している。ルームエアコンディショナー（以 下、「エアコン」という) は採用率が小さいものの、暖房設備として
の採用が増加している。以前は北海道で多く普及していた石油熱源 の暖房、給湯設備は採用が極めて少なくなっている。

\section{2 事業者規模と設備仕様の関係}

図 9 には、暖房、給湯、換気の各設備仕様について、事業者規模 (年間建設棟数)、事業者所在地、事業者平均推定 $\mathrm{U}_{\mathrm{A}}$ 值（第 1 仕様 について図 5 の 157 通りの各部位面積で算出した $\mathrm{U}_{\mathrm{A}}$ の平均值）と の関係を示す。また、設備仕様の凡例は、煩雑になるのを避けるた め、従来型と潜熱回収型の区別や熱交換の有無を区別せずに、複数

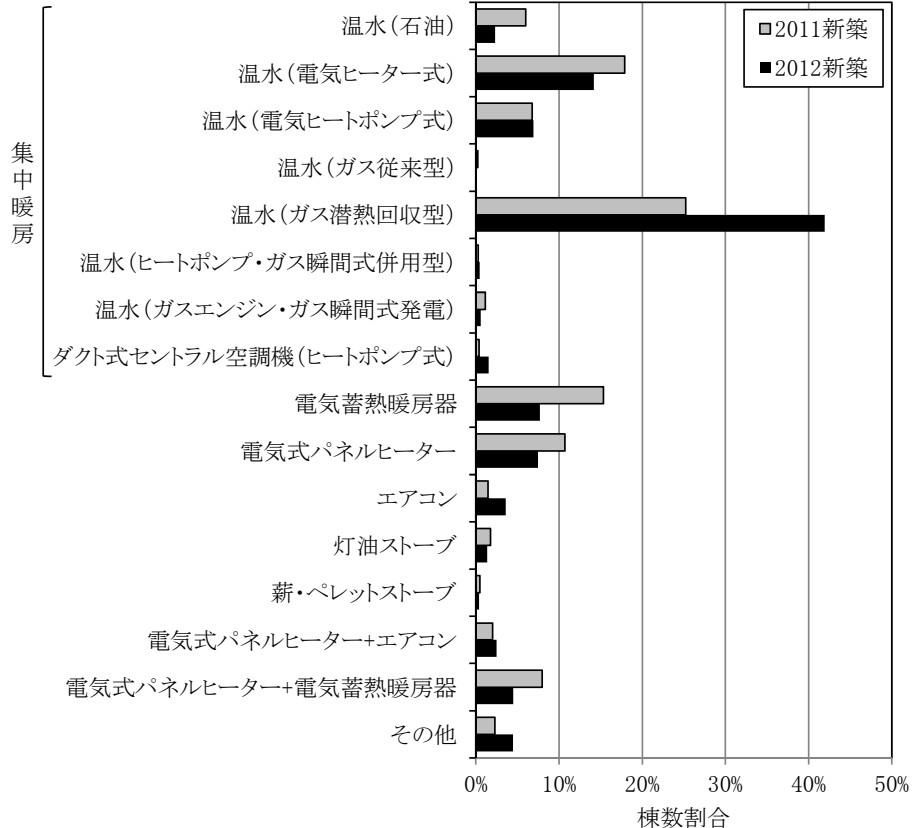

(a)暖房設備

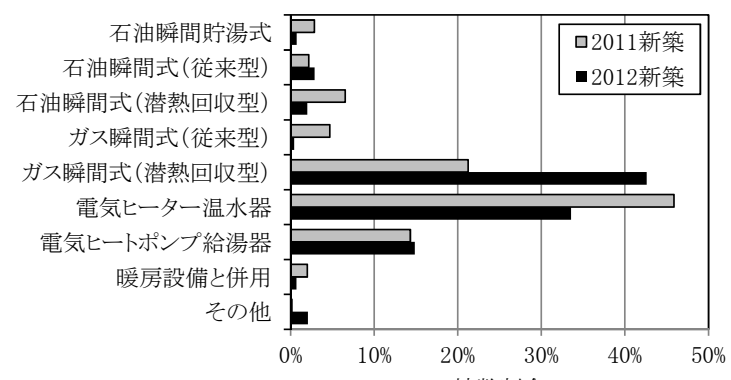

(b)給湯設備 棟数割合

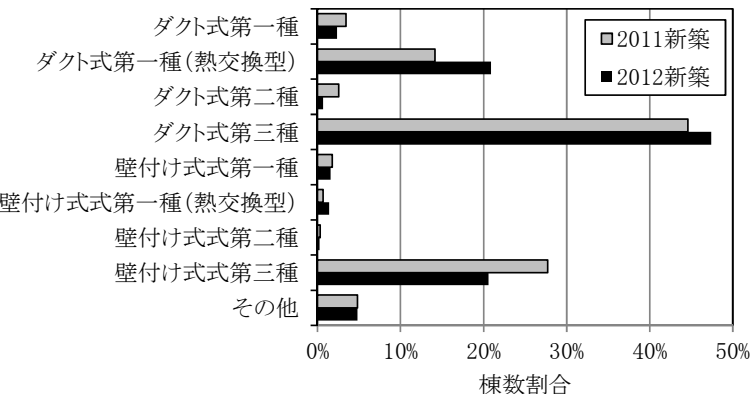

(c)換気設備

図 8 設備仕様の調査結果（2011 年と 2012 年の比較）

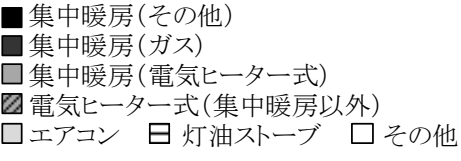

事業者規模

3 棟以下

10 棟以下

50 棟以下

51 棟以上

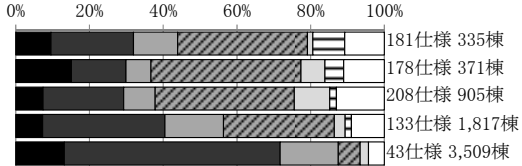

事業者所在地

大規模事業者

空知・石狩・後志

胆振・日高

渡島・桧山

上川・留萌・宗谷

オホーツク

十勝

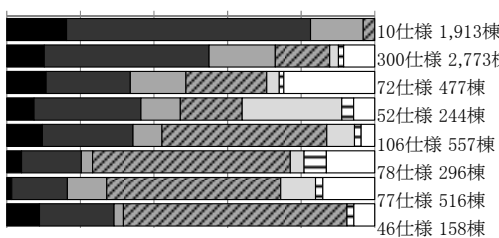

石油給湯器

ガス給湯器

電気ヒーター温水器

ロ電気ヒートポンプ給湯器

$\square$ その他
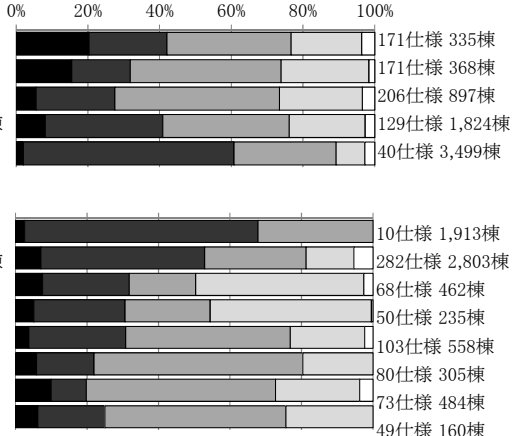

事業者平均推定 $\mathrm{U}_{\mathrm{A}}$ 值

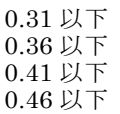

0.46 以下

0.46 を超える

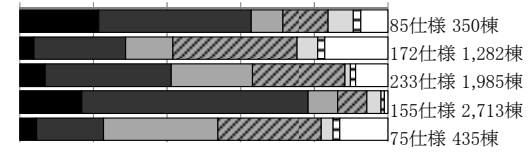

暖房設備

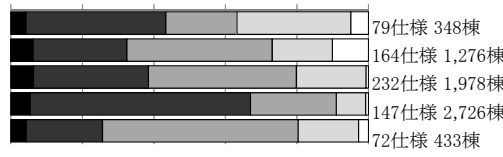

給湯設備
多式管一種換気設備

ダク外式第三種換気設備

壁付讨式第一種換気設備

壁付け式第三種換気設備

口その他
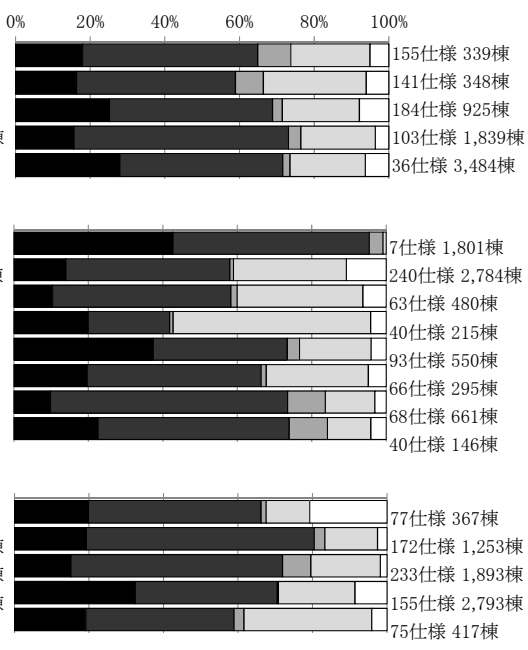

換気設備

図 9 事業者属性別の設備仕様（棟数割合） 
の設備をまとめて示している。

図 9 上段のとおり、事業者規模別で見ると、年間建設棟数 11 棟 以上の事業者で集中暖房の採用が多い。集中暖房の多くは暖房・給 湯併用のガス潜熱回収型熱源機（通称エコジョーズ）を使用してお り、結果としてこれらの事業者でガス給湯器の採用が多くなってい る。電気ヒーターを使用した暖房設備は 51 棟以上の事業者で採用 率が 2 割程度にとどまるが、その他の事業者では約 4 割で採用され ている。エアコンは 4〜10 棟の事業者を主として、中規模事業者で の採用が目立つ。一方、灯油ストーブと石油給湯器は 3 棟以下の小 規模事業者で比較的多く採用されている。

\section{3 地域性}

図 9 中段のとおり、集中暖房は建設地が全道にわたる大規模事業 者のほとんど、また空知・石狩・後志の 7 割以上で採用されている が、その他の地域では半数以下であり、オホーツク、十勝、釧路・ 根室では $2 \sim 3$ 割と、地域差が極めて大きい。

この地域差について参考とするため、都市ガスの普及率と価格、 灯油価格、暖房デグリーデーを表 3 に示す。都市ガスは LP ガスに 比べて同一熱量で $4 \sim 6$ 割程度安価であるため 20)、都市ガスの普及 率がガスを熱源とする設備の使用割合に影響することが考えられる。 そこで、地域別のガス熱源の暖房設備または給湯設備の使用割合を 目的変数、表 3 に示寸都市ガス普及率と都市ガス料金を説明変数と して重回帰分析を行った結果を図 10 に示す。給湯設備については、 都市ガス料金との相関がなかったため説明変数から除いた。都市ガ スの普及率や価格がガス熱源設備の使用割合に影響を与えている可

表 3 都市ガスの普及率・料金、灯油価格、暖房デグリーデー

\begin{tabular}{|c|c|c|c|c|}
\hline 振興局 & $\begin{array}{c}\text { 都市ガス } \\
\text { 普及率 } \\
\end{array}$ & $\begin{array}{c}\text { 都市ガス料金 } \\
\text { [円/月] }\end{array}$ & $\begin{array}{c}\text { 灯油価格 } \\
{[\mathrm{P} / \mathrm{L}]} \\
\end{array}$ & $\begin{array}{c}\text { 暖房デグリーデー } \\
\mathrm{D}_{18-18}[\mathrm{~K} \text { 日 }]\end{array}$ \\
\hline 石狩·空知・後志 & $35 \%$ & 9,393 & \begin{tabular}{|l|}
89.7 \\
\end{tabular} & 3,587 \\
\hline 胆振・日高 & $26 \%$ & 10,094 & 93.1 & 3,849 \\
\hline 渡島・檜山 & $29 \%$ & 9,262 & 98.1 & 3,419 \\
\hline 上川·留萌·宗谷 & $32 \%$ & 8,396 & 93.9 & 4,270 \\
\hline オホーツク & $12 \%$ & 9,198 & 94.6 & 4,478 \\
\hline 十勝 & $19 \%$ & 11,346 & 90.9 & 4,247 \\
\hline 釧路•根室 & $45 \%$ & 7,932 & 95.9 & 4,264 \\
\hline
\end{tabular}

算出根拠

都市ガス普及率：文献21)による2011年度末のメーター取付け個数を 2012 年3月の住民基本台帳世帯数 (供給区域外を含む当該 振興局全域の世帯数) で除した值。

都市ガス料金：文献20)による $2009 \mathrm{MJ} /$ 月(LPガス $20 \mathrm{~m}^{3}$ の熱量相当)使 用時の料金(税込)。複数の供給事業者数がある場合は メーター取付け個数による加重平均值と寸る。

灯油価格：文献22)による多量買い、配達料込久、税込の価格。市 町村別の值の世帯数による加重平均值とする。 暖房温度 $18^{\circ} \mathrm{C}$ のささ暖房度日数。図 3 に記載の都市

$\mathrm{D}_{18-18}$ : の標準年EA気象データ ${ }^{18}$ による。

\begin{tabular}{|c|c|c|}
\hline 説明変数 & 偏回帰係数 & $\mathrm{p}$ 值 \\
\hline 都市ガス普及率 & 0.52 & 0.37 \\
\hline 都市ガス料金[円/月] & $1.47 \mathrm{E}^{-0} 05$ & 0.78 \\
\hline 定数項 & -0.039 & 0.95 \\
\hline 重相関係数 & 0.48 & \\
\hline \multicolumn{3}{|c|}{ 目的変数:ガス熱源の給湯設備の使用割合 } \\
\hline 説明変数 & 偏回帰係数 & $\mathrm{p}$ 值 \\
\hline 都市ガス普及率 & 0.48 & 0.30 \\
\hline 定数項 & 0.10 & 0.45 \\
\hline 重相関係数 & 0.46 & \\
\hline
\end{tabular}

図 10 ガス熱源設備の使用割合に関する重回帰分析の結果
能性はあるものの、空知・石狩・後志では都市ガス普及率と比べて ガス熱源設備の採用率が高い、釧路・根室は都市ガス普及率が最も 高く料金も低いにもかかわらずガス熱源設備の採用率が低いなど、 必ずしも都市ガスの供給状況だけでは説明できない点がある。灯油 価格についてはガスに比べて地域差が少ない。

集中暖房の少ない地域について見ると、比較的温暖で暖房デグリ ーデーが小さい胆振・日高、渡島・檜山においては、エアコンや電 気ヒートポンプ給湯器（通称エコキュート）の使用割合が他地域に 比べ多い。エアコンのみで暖房を行うケースは渡島・檜山で $27 \%$ と 突出しているが、胆振・日高でも「電気式パネルヒーター+エアコ ン」(「その他」に含まれる) の組み合わせが $20 \%$ を占めている。一 方、上川、オホーツク、十勝、釧路・根室では、電気蓄熱暖房器、 電気式パネルヒーターといった電気ヒーター式の暖房機器や電気ヒ ーター温水器を $5 \sim 6$ 割で採用している。

換気設備はダクト式が全体の過半を占めるが、渡島・檜山では約 4 割と少ない。ダクト式の第一種換気設備は大規模事業者と上川 ・ 留萌・宗谷で多く採用されている。

\section{$4.4 U_{A}$ 值と設備仕様の関係}

図 9 下段のとおり、1、2 地域の省エネ基準を満たす中で最も基準 值に近い $\mathrm{U}_{\mathrm{A}}$ 值 $0.46 \mathrm{~W} /\left(\mathrm{m}^{2} \mathrm{~K}\right)$ 以下のカテゴリーとトップランナーと 言える $0.31 \mathrm{~W} /\left(\mathrm{m}^{2} \mathrm{~K}\right)$ 以下のカテゴリーでは、集中暖房やダクト式第 一種換気設備など、比較的システム価格が高くなりやすい設備の採 用が多く、住宅の断熱水準によって採用設備は双峰型の分布をなし ている。これは、 $\mathrm{U}_{\mathrm{A}} \leqq 0.46 \mathrm{~W} /\left(\mathrm{m}^{2} \mathrm{~K}\right)$ のカテゴリーに大規模事業者の 多くが含まれていることと、断熱性能の高い住宅では設備も高効率 の機器が採用される傾向があることに起因すると考えられる。一方、 $\mathrm{U}_{\mathrm{A}}$ 值が $0.46 \mathrm{~W} /\left(\mathrm{m}^{2} \mathrm{~K}\right)$ を超える事業者は、電気ヒーター式の設備や 壁付け式第三種換気設備など低価格の設備機器を比較的多く採用す る傾向が見られる。

\section{5. 地域別の一次エネルギー消費量の推定 5.1 検討の目的}

設備仕様の調查結果の事業者属性による分析から、地域による採 用設備の傾向に違いが大きいことがわかった。特に電気ヒーター式 の設備が多く採用されている地域では、一次エネルギー消費量が大 きくなることが予想される。そこで、調査により把握した断熱・設 備仕様により、地域別の一次エネルギー消費量の推定を行う。

\section{2 各種条件の仮定と一次エネルギー消費量の推定方法}

断熱仕様と暖房、給湯、換気の各設備仕様は互いに関連付けせず にそれぞれの代表仕様を調査しているが、表 1(c)を参照すると第 1 仕様の回答棟数が合計棟数の 8〜9 割を占めているため、各事業者 の第 1 仕様同士の組み合わせで検討しても概ねの傾向は把握できる と考えられる。このことから、以下では各社の第 1 仕様で検討を行 う。

計算条件を表 4 に示す。表 $4(\mathrm{a})$ に記載のとおり、事業者ごとに断 熱仕様 (平均 $\mathrm{U}_{\mathrm{A}}$ 值)、設備仕様、所在地の省エネルギー基準上の地 域区分を反映させ、一次エネルギー消費量を計算する。事業者ごと の棟数は、各設備第 1 仕様の棟数のうち最小值を用いることとする。

計算には住宅の省エネルギー基準の告示に沿った計算方法として 公開されている「住宅・住戸の省エネルギー性能の判定プログラム 
Version 1.12」23)を用い、表 4(b)のとおり計算条件を設定する。日 射取得熱量は外壁、天井、屋根の熱貫流率を $\mathrm{U}_{\mathrm{A}}$ 值で線形回帰し、 ガラスを日射取得型の Low-E 複層ガラス、取得日射量補正係数を 0.51 として、 $\mathrm{m}_{\mathrm{H}}$ 值を $\mathrm{U}_{\mathrm{A}}$ 值の一次関数で表現する注 ${ }^{5}$ 。設備の省エ ネルギー対策を行わないとした場合に特に効率が低く計算される石 油およびガス熱源の給湯機については文献 16)を参考に効率を設定 し主 6)、その他の設備は「特に省エネルギー対策をしていない」を選 択する。また、プログラムに選択肢がある設備の種類以外は「その 他の機器」を選択寸る。なお、暖房一次エネルギー消費量は地域区 分、設備仕様ごとに $\mathrm{U}_{\mathrm{A}}$ 值の 2 次関数による近似式で算出する注 7)。 省エネルギー基準への適合は冷房、照明、家電などその他設備、発 電量を加えた合計で判断されるが、ここでは調査対象とした暖房、 給湯、換気に関する一次エネルギー消費量に限って計算を行う。

\section{3 一次エネルギー消費量の推定結果}

図 11 に推定した一次エネルギー消費量の内訳を示す。省エネル ギー基準值は地域区分之暖房設備の仕様により異なるが、それぞれ の棟数で加重平均した值を示している。電気ヒーター式の設備を使 用すると一次エネルギー消費量が非常に大きくなる影響で、暖房、 給湯とも平均值としては省エネ基準值を上回っている。換気設備も 熱交換換気設備の影響により基準值を上回っている。

図 12 は事業者所在地別の一次エネルギー消費量推定值である。 また図 7 と同様に Z 検定の結果を㶰印で示している注4)。地域による 差は大きく、標準偏差の範囲内でも、消費量の少ない空知・石狩・ 後志、渡島・檜山と、主に省エネルギー基準の地域区分で 1 地域に 所在する振興局では 3 倍以上の差がある。暖房、給湯、換気に関す

\section{表 4 計算条件}

\begin{tabular}{|c|c|c|}
\hline 項目 & \multicolumn{2}{|l|}{ 桘定 } \\
\hline 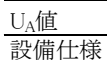 & \multicolumn{2}{|c|}{$\begin{array}{l}\text { 第1仕様について図5の157通りの組み合わせで計算した平均 } U_{\mathrm{A}} \text { 値 } \\
\text { 笼房、給湯、換気の各設備第1仕㥞の組み合わせ }\end{array}$} \\
\hline 地域区分 & \multicolumn{2}{|c|}{\begin{tabular}{|l} 
事業者が所在する市町村の省エネルギー基隻上の地域区分 \\
(大規模事業者は2地域に所在するとして扱う) \\
\end{tabular}} \\
\hline 棟数 & \multicolumn{2}{|c|}{ 暖房、給湯、換気の各設備第1仕様の棟数の最小値 } \\
\hline \multicolumn{3}{|c|}{ (b)共通の設定条件 } \\
\hline 分類 & 項目 & 設定 \\
\hline \multirow{4}{*}{ 面積 } & 主たる居室の面積 $\left[\mathrm{m}^{2}\right]$ & 57.11 \\
\hline & その他の居室の面積[m²] & 図5に示寸住宅 \\
\hline & 床面積の合計 $\left[m^{2}\right]$ & -の平均値 \\
\hline & 外皮面積 $\left[\mathrm{m}^{2}\right]$ & 347.3 \\
\hline \multirow[t]{2}{*}{ 日射取得 } & $\begin{array}{l}\text { 単位日射強度あたりの暖房期日 } \\
\text { 射熱取得量( } \mathrm{m}_{\mathrm{H}} \text { 值) }\left[\mathrm{W} /\left(\mathrm{W} / \mathrm{m}^{2}\right)\right]\end{array}$ & $\begin{array}{l}1 \text { 地域 } 5.61 \mathrm{U}_{\mathrm{A}}+4.80 \\
2 \text { 地域 } 5.48 \mathrm{U}_{\mathrm{A}}+4.52 \\
3 \text { 地域 } 5.49 \mathrm{U}_{\mathrm{A}}+4.50\end{array}$ \\
\hline & 蓄熱の利用 & 利用しない \\
\hline \multirow[b]{2}{*}{ 暖房設備 } & 温水式暖房の配管 & 断熱配管を採用する \\
\hline & \begin{tabular}{|l} 
エアコン、灯油ストーブ、温水暖 \\
房の熱源機
\end{tabular} & 特に省エネルギー対策をしていない \\
\hline \multirow{6}{*}{ 給湯設備 } & 機器効率 & \begin{tabular}{|l|} 
石油従来型77.8\%,石油潜熱回収型 \\
$89.7 \%$ 、ガス従来型78.2\%、ガス潜熱回 \\
収型 $90.5 \%$ 、その他機器は効率を入力 \\
しない
\end{tabular} \\
\hline & \begin{tabular}{|l} 
子ろ機能の種類 \\
\end{tabular} & \begin{tabular}{|l|l|} 
ふろ給湯機 (追焚あり) \\
\end{tabular} \\
\hline & 配管方式 & 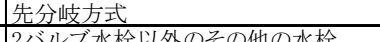 \\
\hline & 節㨽㳻措置 & $\begin{array}{l}\text { 2バルブ水栓以外のその他の水栓 } \\
\text { 採用しない }\end{array}$ \\
\hline & 逧槽の保温措置 & 高断熱浴槽を使用しない \\
\hline & 太陽熱利用給湯設備 & 採用しない \\
\hline \multirow{3}{*}{ 換気設備 } & $\begin{array}{l}\text { 換気設備のび省エネルギー対策の } \\
\text { 有無および類 }\end{array}$ & 特に省エネルギー対策をしていない \\
\hline & 換気回数 & 0.5 回 $/ \mathrm{h}$ \\
\hline & $\begin{array}{l}\text { 第一種換気設備の場合における } \\
\text { 有効換気量率 }\end{array}$ & 1.00 \\
\hline
\end{tabular}

る一次エネルギー消費量の合計で省エネルギー基準值を満たす割合 は、1、2、3 地域でそれぞれ $27 \% 、 60 \% 、 69 \%$ と推定され、 1 地域 で特に低い。

図 13 は特に一次エネルギー消費量が多い 1 地域について、電気 ヒーター式の設備の使用有無と一次エネルギー消費量の関係を示し ている。暖房、給湯における電気ヒーター式設備の使用有無により、 一次エネルギー消費量が大きく変わることがわかる。給湯、暖房の いずれかに電気ヒーター式の設備を使用している場合は、暖房、給 湯、換気の合計で省エネルギー基準值を満たすケースがなかった。

以上のように、採用される設備の傾向の違いにより、一次エネル ギー消費量に大きな地域差が生じ、特に電気ヒーター式の設備が多 く使用されている地域では、省エネルギー基準を満たさない可能性 のある住宅が多いことがわかった。

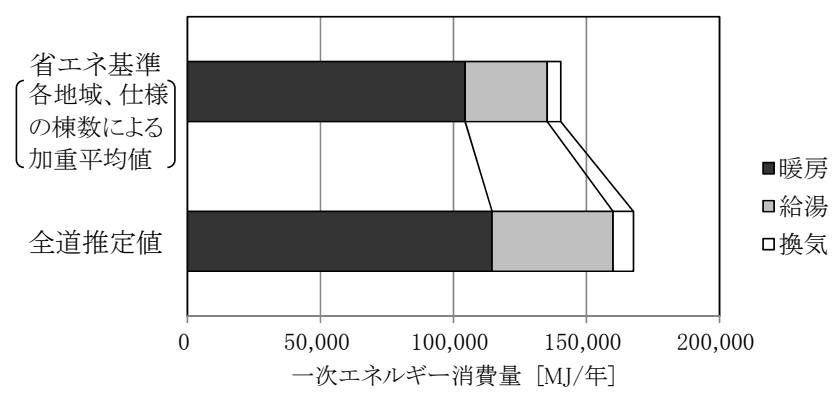

図 11 一次エネルギー消費量の内訳

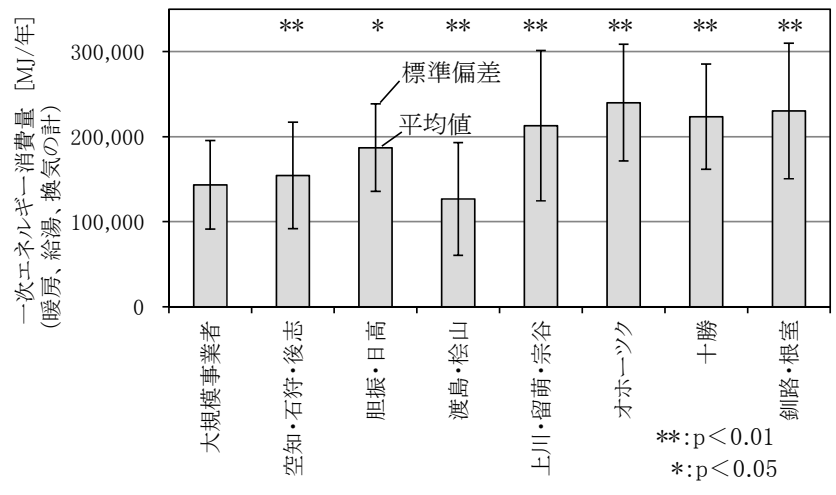

図 12 事業者所在地別の一次エネルギー消費量推定値

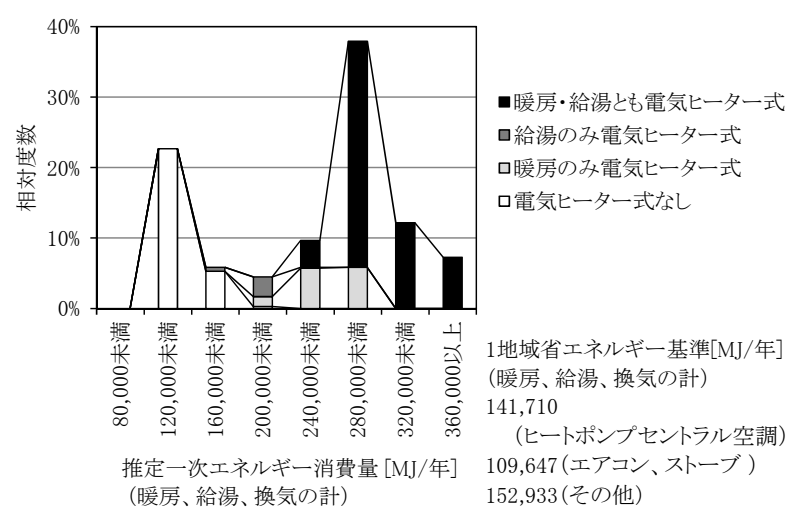

図 131 地域の設備仕様と一次エネルギー消費量 


\section{6. 設備仕様の選択要因}

\section{1 設備仕様の選択要因に関する調査結果}

先に見たように、設備仕様の地域性には気候 (暖房デグリーデー) や都市ガスの供給状況が関係していると考えられる。一方、個々の 住宅においては、いくつかの選択肢の中から、事業者や建築主の意 向により採用する設備が決定されていると考えられる。

図 14 に設備（暖房・給湯）仕様の選択要因に関する調査結果を 示す。事業者を対象とした調査結果ではあるが、図 14(a)を見ると、 $85 \%$ が「事業者が提案」または「どちらかというと事業者が提案」 と回答している。暖房設備と給湯設備では同時に決まるケースが過 半だが、どちらかが先に決まる場合は暖房が優先することが多い(図 14(b))。最終決定要因はコス卜関係が 8 割以上を占めている（図 $14(\mathrm{c})$ )。

\section{2 設備仕様の選択要因に関する考察}

設問では暖房と給湯設備を区別していないため、図 15 に示寸各 社第 1 仕様の設備の組み合わせのうち、10 社以上で回答のあった組 み合わせを対象に、それぞれの設備仕様の提案者と最終決定要因の 傾向を考察する。図 16 に、図 14 の凡例に括弧書きで示した点数に より数值化した、設備仕様の提案者と最終決定要因の位置関係（平 均値）を示す。最終決定要因については、イニシャルコストに相当 する「設備価格・施工コスト」と運用コストに相当する「燃料代・ 電気代」のみに着目している。

設備仕様の提案はいずれの組み合わせでも事業者側に主導権があ ることがわかる。特にヒートポンプ熱源の機器は事業者側の提案が 強く、エアコンで暖房を行う方式はもっぱら事業者からの提案で選 択されていると考えられる。一方、コストに関しては、設備によっ てイニシャルコストで決まる場合と運用コストで決まる場合とに分 かれている。特にエアコンや電気ヒートポンプ給湯器は運用コスト が最終決定要因になっているケースが多い。逆に、温水暖房 (石油) や灯油ストーブ、電気式パネルヒーター、石油瞬間給湯器 (従来型) など従来型の機器は、初期コストが優先しており、建築主側の提案 によることが比較的多い傾向がわかる。

\section{7. まとめ}

本研究では、北海道内の住宅建設事業者を対象に新築戸建住宅の 断熱および設備仕様の実態調查を実施し、一次エネルギー消費量の 推定と設備仕様の選択要因に関する考察を行った。得られた主な結 論は次のとおりである。

（1）各部位の断熱仕様の調査結果から外皮断面構成や各部位面積な どを仮定し $\mathrm{U}_{\mathrm{A}}$ 值の推定を行った。その結果、2012 年新築戸建て 住宅で $\mathrm{U}_{\mathrm{A}}$ 值基準を満たす割合は 1、2、3 地域それぞれで $89 \%$ 、 90\%、99\%と推定された。また、地域間で建物形状を同一とする 仮定のもとでは、 $\mathrm{U}_{\mathrm{A}}$ の平均值には地域差が見られるものの、気候 による暖房負荷の差を埋め合わせるほどの断熱性能の違いはない。

（2） 2011 年新築と 2012 年新築の戸建て住宅に採用された設備を比 較すると、電気ヒーター式の設備の減少が顕著である一方、潜熱 回収型のガス機器が大きく増加している。エアコンは採用率が小 さいものの、暖房機器としての採用が増加している。

（3）設備仕様と事業者属性との関係を分析した結果、特に事業者所 在地による設備仕様の違いが大きく、空知・石狩・後志で集中暖

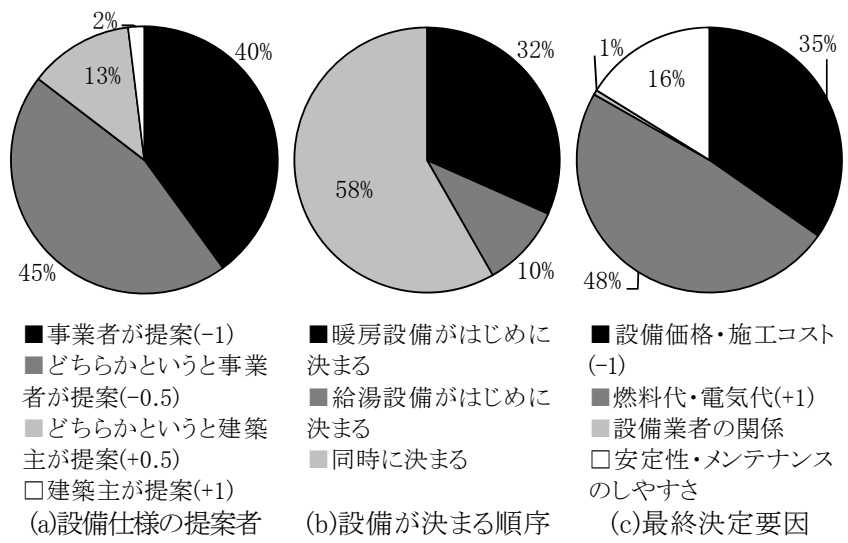

図 14 設備（暖房・給湯）の選択要因（回答事業者の割合、 $\mathrm{N}=513 ）$

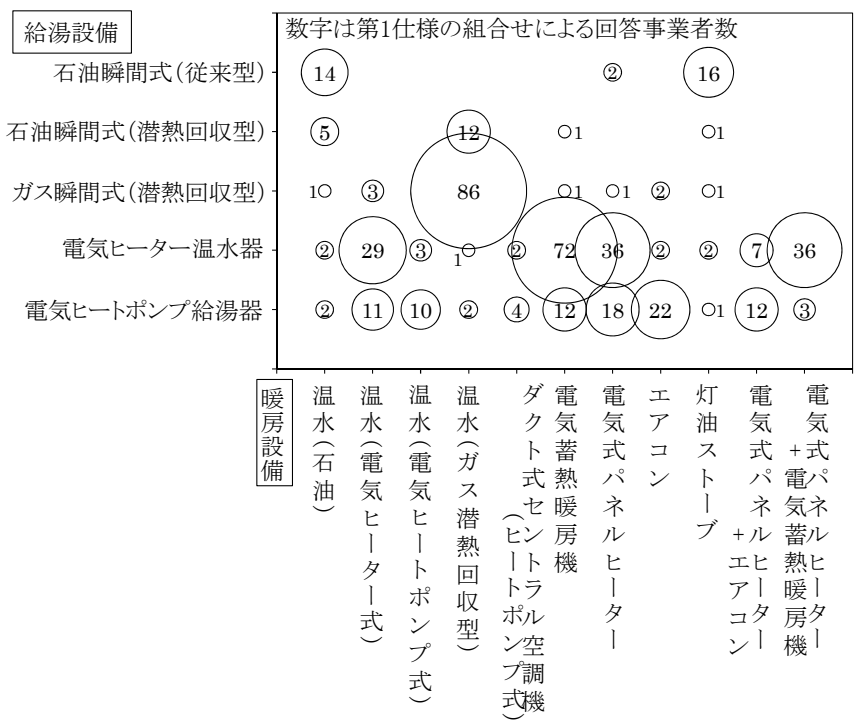

図 15 主な暖房・給湯設備の組み合わせと回答事業者数

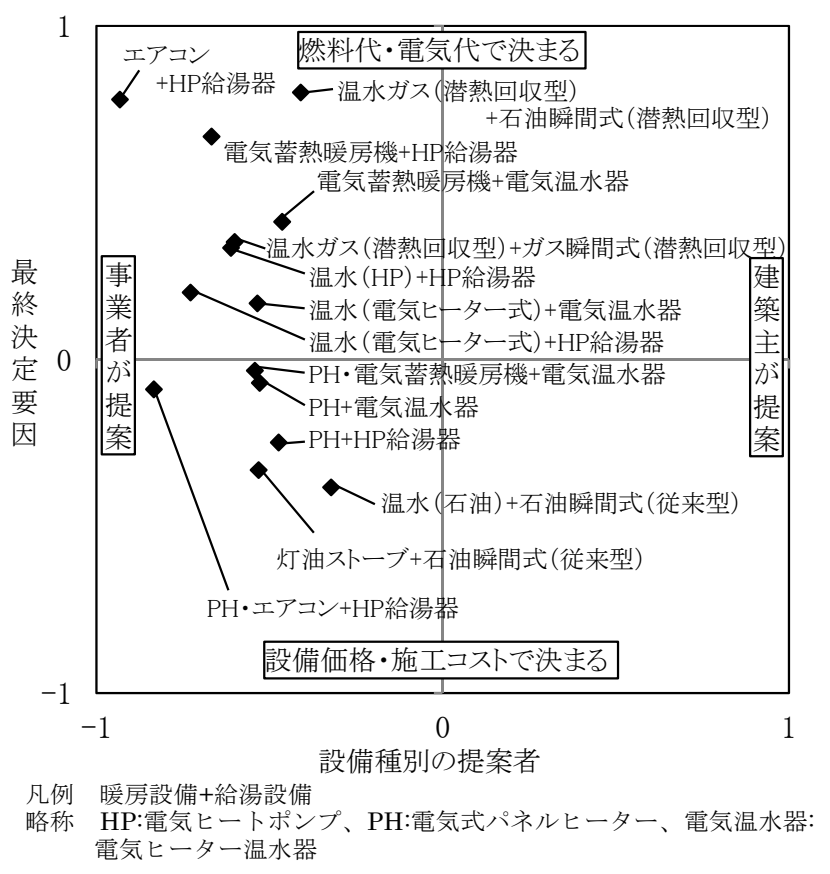

図 16 暖房、給湯設備の組み合わせによる選択要因の傾向 
房が多いこと、渡島・檜山、胆振・日高で暖房用のエアコンや電 気ヒートポンプ給湯器の普及が進んでいること、上川・留萌・宗 谷、オホーツク、十勝、釧路・根室で電気ヒーター式の機器が依 然として多く採用されていることがわかった。

（4）省エネルギー性能の判定プログラムを用いて各種仮定に基づき 一次エネルギー消費量を推定した結果、暖房、給湯、換気の合計 で省エネルギー基準を満たすのは、1、2、3 地域それぞれ $27 \%$ 、 60\%、69\%と、 $\mathrm{U}_{\mathrm{A}}$ 值基準の達成率よりも低いことがわかった。特 に、1 地域では電気ヒーター式の設備の使用割合が大きいことに より、一次エネルギー消費量が大きくなっている。

（5）設備仕様の提案に際しては事業者に主導権があることがわかっ た。特に暖房用のエアコンなど新たな設備は事業者によって普及 が進んでいると考えられることから、事業者に対して適切な情報 を提供していくことが重要である。

なお、本研究で推定した $\mathrm{U}_{\mathrm{A}}$ 值や一次エネルギー消費量は、建物 形状や仕様の各種仮定に基づくものであり、省エネルギー基準に準 拠した算定方法が複数示されている場合には、採用する算定方法に よっても異なる結果が得られることに留意する必要がある。

\section{謝辞}

本研究は道受託研究「北海道型ゼロエミッション住宅に関する研 究」の一環として実施した。また、調査に当たっては、道内の住宅 建設事業者のみなさまに多大なご協力をいただきました。記して感 謝の意を表します。

\section{参考文献}

1）エネルギーの使用の合理化に関する建築主等及び特定建築物の所有者の 判断の基準, 平成 11 年 3 月 30 日通商産業省・建設省告示第 2 号

2) 北方型住宅の設計と施工, 北海道建築士会, p.78, 1991.1

3）立松宏一, 福島明, 鈴木大隆, 月館司, 廣田誠一, 高倉政寛, 池田裕雅 : 北海道における高断熱戸建て住宅の温熱環境とエネルギー消費の実態 熱 損失係数が $1.3 \mathrm{~W} / \mathrm{m}^{2} \mathrm{~K}$ レベルの住宅を主たる対象とした調査, 日本建築学 会環境系論文集，No.679，pp.713-720，2012.9

4) 住宅事業建築主の新築する特定住宅の外壁, 壁等を通しての熱の損失の防 止及び住宅に設ける空気調和設備等に係るエネルギーの効率的利用のため に特定住宅に必要とされる性能の向上に関する住宅事業建築主の判断基準, 平成 21 年 1 月 30 日経済産業省・国土交通省告示第 2 号

5）住宅に係るエネルギーの使用の合理化に関する建築主の判断の基準，平成 25 年 1 月 31 日経済産業省・国土交通省告示第 1 号

6) フラット 35 住宅仕様実態調査報告, 住宅金融支援機構, http://www.jhf.go.jp/about/research/, 参照 2014.6.9

7）砂川雅彦，小坂信二 : 断熱材出荷統計を利用した既築住宅の省エネルギー 基準別戸数の推計手法, 日本建築学会大会学術講演梗概集 D-2, pp.211-212, 2005.9

8) ガス石油機器の販売実績と予測, 日本ガス石油機器工業会, http://www.jgka.or.jp/industry/toukei/kougyo-toukei/hanbai-jisseki/, 参 照 2014.6.9 閲覧

9）家庭用エアコン・業務用エアコン・ガスヒートポンプエアコン, 家庭用ヒ ートポンプ給湯機の月ごとの国内出荷の推移, 日本冷凍空調工業会, http://www.jraia.or.jp/statistic/，参照 2014.6 .9

10）岸田真一, 中村美紀子, 三浦尚志, 桑沢保夫, 石婷 : アンケートによる 住宅設備・機器の使用状況に関する実態調査, その 1 調査の目的・概要 および調査方法，日本建築学会大会学術講演梗概集 D-2, pp.987-988, 2010.9

11）三浦秀一：全国における住宅の用途別エネルギー消費と地域特性に関す る研究, 日本建築学会計画系論文集, No.51, pp. 77-83, 1998.8

12）福代和宏 : 二人以上世帯エネルギー源別年間消費量の地域性の要因, 空 気調和・衛生工学会論文集, No.145, pp.9-19, 2009.4
13）久米蒠, 海藤俊介, 松野勉, 横尾昇剛, 岡建雄 : 住宅設備 - 部材の選択 要因に関寸る研究, 日本建築学会大会学術講演梗概集 D-2, pp.1407-1408, 2010.9

14）立松宏一，廣田誠一，鈴木大隆，福島明：持続可能な地域のための住ま いづくりに関する研究, その 11 北海道の新築戸建て住宅を対象とした断 熱仕様調査, 日本建築学会北海道支部研究報告集, No.85, pp.223-226, 2012.6

15）立松宏一, 廣田誠一, 鈴木大隆, 遠藤卓, 福島明：持続可能な地域のた めの住まいづくりに関する研究，その 13 北海道の新築住宅の断熱・設備 仕様調査, 日本建築学会北海道支部研究報告集, No.86, pp.229-232, 2013.6 16）平成 25 年住宅・建築物の省エネルギー基準解説書編集委員会 : 平成 25 年省エネルギー基準に準拠した算定・判断の方法及び解説（II 住宅），建 築環境・省エネルギー機構, 2013.5

17）堀江悟郎，荒谷登，本間宏，横平昭：木造住宅の自然温度，日本建築学 会論文報告集号外, p.421，1966.10

18）拡張アメダス気象データ 1981-2000, 日本建築学会, 2005.8

19）北方型住宅の熱環境計画，北海道建築技術協会，2010.1

20）家庭用ガス料金一覧表，経済産業省北海道経済産業局， http://www.hkd.meti.go.jp/hokpg/infopen/kateiyou.htm, 更新 2013.12.5, 参照 2014.6 .9

21）第 120 回 (平成 25 年) 北海道統計書, 北海道 http://www.pref.hokkaido. lg.jp/ss/tuk/920hsy/13.htm，参照 2014.6.9

22）灯油・LP ガス・ガソリン価格調査 2012 年 3 月分, 北海道消費者協会, http://www.syouhisya.or.jp/research.html, 参照 2014.6 .9

23）住宅・住戸の省エネルギー性能の判定プログラムVersion 1.12, 建築研 究所, http://house.app.lowenergy.jp/, 参照 2014.6.9

24）高倉政寛，伊庭千恵美，遠藤卓，長谷川雅浩，鈴木大隆：持続可能な地 域のための住まいづくりに関する研究，その 6 新築戸建住宅の属性（工 法，仕様等），日本建築学会北海道支部研究報告集，No.84，pp.409-414， 2011.7

25）立松宏一，高倉政寛，月館司，鈴木大隆：北海道内の新築戸建て住宅の 断熱・設備仕様実態調査，その 2 設備種別の実態把握と決定要因に関す る考察, 日本建築学会大会学術講演梗概集, 環境工学 I, pp.1005-1006, 2014.9

注

注 1）調査票の選択肢から熱伝導率が一意に決まらない主な断熱材について、 断熱材の性能差がもたらす推定誤差の参考とするため、熱伝導率を複数 ある規格值のうち本文の計算に使用した值から最も乘離した值に置き 換えて平均 $\mathrm{U}_{\mathrm{A}}$ 值を計算した結果を付表 1 に示す。変更前の平均 $\mathrm{U}_{\mathrm{A}}$ 值 (図 6 に記載の平均 $\mathrm{U}_{\mathrm{A}}$ 值を小数点以下第 3 位まで記載すると $\left.0.392 \mathrm{~W} /\left(\mathrm{m}^{2} \mathrm{~K}\right)\right)$ に対し、それぞれの断熱材で熱伝導率を変更したこと による平均 $\mathrm{U}_{\mathrm{A}}$ 值の変化は $1 \%$ 以内である。

注 2) 2011 年 2 月に道内の住宅建設事業者を対象に実施した調査 ${ }^{24)}$ では、木 造軸組工法が $73.1 \%$ 、枠組壁工法が $26.4 \%$ 、その他木造が $0.5 \%$ 新築 棟数割合となっているが、本調査では工法を尋数ていないため、すべて 木造軸組工法の熱橋面積比率を用いた。なお、文献 16$)$ には熱貫流率の簡 略計算方法として、木造軸組工法と枠組壁工法に分けて熱橋面積比率が 示されており、すべて木造軸組工法の熱橋面積比率で算出した平均 $\mathrm{U}_{\mathrm{A}}$ 值 $0.392 \mathrm{~W} /\left(\mathrm{m}^{2} \mathrm{~K}\right)$ に対し、両工法の熱橋面積比率を用い上記の棟数割合 による加重平均（その他木造は考慮しない）で算出した平均 $\mathrm{U}_{\mathrm{A}}$ 值は $0.394 \mathrm{~W} /\left(\mathrm{m}^{2} \mathrm{~K}\right)$ である。

注 3） $\mathrm{U}_{\mathrm{A}}$ 值は建物外皮の各部位面積を用いて算出するため、実住宅の各部位 面積の実態を反映させる必要がある。そこで、建築主から了解を得た北 方型住宅を対象に各部位面積を図面から調査し計算に用いた。参考に、 調査で得られた「断熱仕様（679 仕様）」と「各部位面積の組み合わせ (157 通り)」の一方を平均值で固定して計算した $\mathrm{U}_{\mathrm{A}}$ 值の累積度数を付 図 1 に示す。 $\mathrm{U}_{\mathrm{A}}$ 值の度数分布や標準偏差は、住宅形状のばらつきを考 慮したほうがより現実に近くなると考えたため、図 6〜図 7 の分析では 住宅形状 157 通りで計算を行った結果を用いた。ただし、地域別の建物 形状傾向の違いは反映できていない。

注 4) 各カテゴリーにおいて、当該カテゴリーと当該カテゴリーを除くその他 カテゴリーをまとめた標本の 2 群で母平均の差の検定を行った。検定方 法は $\mathrm{Z}$ 検定 (両側) とした。なお、平均值や標準偏差は棟数を考慮して 算出したが、 $\mathrm{p}$ 值はサンプルサイズが大きくなるほど小さくなる傾向が あるため、サンプルサイズは実回答数（図 7 は 679 、図 12 は 471）と 
して検定を行った。

注 5）暖房一次エネルギー消費量を $\mathrm{U}_{\mathrm{A}}$ 值の関数として表すため、 $\mathrm{m}_{\mathrm{H}}$ 值の計算 に必要な外皮の熱貫流率は調査データの線形回帰により $\mathrm{U}_{\mathrm{A}}$ 值の一次関 数で求めることとした。ガラスの日射熱取得率は本調査おいて Low-E 複 層ガラスの採用率が $90 \%$ と大部分であったため、日射取得型の Low-E 複 層ガラスの值 0.64 を用いることとした。取得日射量補正係数は、住宅 の省エネルギー基準に準拠した簡易な計算方法として、庇の有無にかか わらず適用可能な定数が示されている ${ }^{16)}$ 。この係数は、暖房負荷が安全 側（暖房負荷が増大寸る）で算出されるよう、日除けの条件が厳しく想
定されている。方位別面積は図 5 に示す住宅の平均值を用いた。 注 6) 文献 16)の p.909、p.924 に記載されている各社給湯機器の効率を参考 に、平均的な值として設定した。

注 7）付図 2 にエアコンと温水暖房（ガス潜熱回収型）を例に、 $\mathrm{U}_{\mathrm{A}}$ 值と暖房 一次エネルギー消費量の関係を示す。暖房一次エネルギー消費量は $\mathrm{U}_{\mathrm{A}}$ の 2 次関数によりよく近似できるため、各地域区分で $\mathrm{U}_{\mathrm{A}}$ の最小值、平 均值、最大值の 3 点で暖房一次エネルギー消費量を算出して 2 次関数の 係数を求めておき、計算に用いた。近似式の係数一覧を付表 2 に示す。

\section{付表 1 断熱材の性能差による $U_{A}$ 值推定への影響}

\begin{tabular}{|c|c|c|c|c|c|c|c|}
\hline \multirow[b]{2}{*}{ 断熱材の種類 } & \multicolumn{3}{|c|}{ 熱伝導率置き換え前 (本文の計算値) } & \multicolumn{3}{|c|}{ 熱伝導率置き換え後 } & \multirow[b]{2}{*}{ (4) $/(2)$} \\
\hline & 規格 & $\begin{array}{c}\text { 熱伝導率 } \\
{[\mathrm{W} /(\mathrm{mK})](1)}\end{array}$ & $\begin{array}{c}\text { 平均 } \mathrm{U}_{\mathrm{A}} \text { 值 } \\
{\left[\mathrm{W} /\left(\mathrm{m}^{2} \mathrm{~K}\right)\right](\text { (2) })}\end{array}$ & 規格 & $\begin{array}{c}\text { 熱伝導率 } \\
{[\mathrm{W} /(\mathrm{mK})](\text { (3) })}\end{array}$ & $\begin{array}{l}\text { 熱伝導率を(1)から (3)に置き換えて } \\
\text { 計算した平均 } \mathrm{U}_{\mathrm{A}} \text { 値 }\left[\mathrm{W} /\left(\mathrm{m}^{2} \mathrm{~K}\right)\right](\text { (4) }\end{array}$ & \\
\hline 高性能グラスウール & $16 \mathrm{~K}$ 相当 & 0.038 & 0.392 & $24 \mathrm{~K}$ 相当 & 0.036 & 0.388 & $99.0 \%$ \\
\hline 吹付けウレタンフォーム & $\mathrm{A}$ 種1 & 0.032 & 0.392 & $\mathrm{~A}$ 種3 & 0.040 & 0.394 & $100.5 \%$ \\
\hline
\end{tabular}

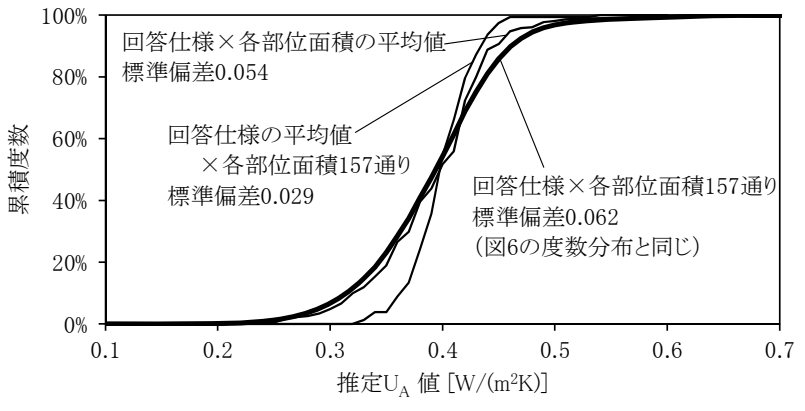

付図 $1 U_{A}$ 值の累積度数

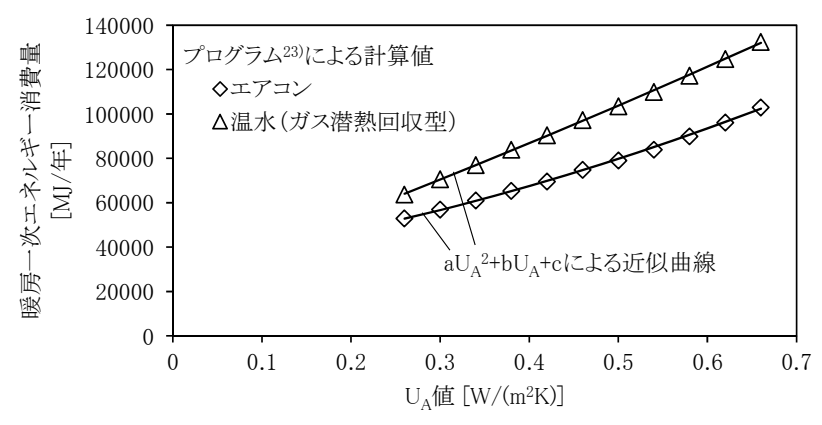

付図 $2 U_{A}$ 值と暖房一次エネルギー消費量の関係（1 地域、熱交換なし）

付表 2 暖房一次エネルギー消費量の近似式の係数一覧（a、b、c は付図 2 中に記載の近似式の係数）

\begin{tabular}{|c|c|c|c|c|c|c|c|c|c|c|c|c|c|c|c|c|c|c|}
\hline 地域区分 & 1 地域 & & & & & & 2地域 & & & & & & 3地域 & & & & & \\
\hline 熱交換換気有無 & なし & & & あり & & & なし & & & あり & & & なし & & & あり & & \\
\hline 係数 & $\mathrm{a}$ & $\mathrm{b}$ & $\mathrm{c}$ & $\mathrm{a}$ & $\mathrm{b}$ & $\mathrm{c}$ & $\mathrm{a}$ & $\mathrm{b}$ & $\mathrm{c}$ & $\mathrm{a}$ & $\mathrm{b}$ & c & $\mathrm{a}$ & $\mathrm{b}$ & $\mathrm{c}$ & $\mathrm{a}$ & $\mathrm{b}$ & $\mathrm{c}$ \\
\hline 温水 (石油) & 36,417 & 61,411 & 34,274 & 2,815 & 185,419 & 12,447 & 54,057 & 132,883 & 30,422 & $-3,571$ & 70,497 & 8,672 & 7,070 & 117,831 & 22,981 & -818 & 128,922 & 7,024 \\
\hline 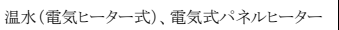 & 461 & 335,888 & 0,321 & 40,975 & 5,543 & 7,788 & 68,040 & 307,660 & 70 & 43,286 & 320,054 & 3,330 & 29,666 & & 90 & 31,1 & & -61 \\
\hline 水 & 9,222 & 180,307 & 16,7 & $-39,115$ & 189,107 & $-1,3$ & 51,110 & 124,291 & & $-36,034$ & 186, & -92 & 21,584 & 89, & & 36,255 & 76,360 & $-1,740$ \\
\hline 温水 (ガス従来型) & , 495 & 156,476 & 32,506 & 3,887 & 179,021 & 11,456 & 54,103 & 127,786 & 28,914 & $-1,798$ & 164,015 & 7,907 & 7,330 & 113,900 & & 310 & 123,984 & 6,315 \\
\hline 温水 (ガス沙 & 673 & 141,711 & 25,1 & 9,931 & & & 51,809 & & & & & & 10, & & & & & \\
\hline (ヒートポンプ式) & $-53,984$ & 195, & 2 & $-32,0$ & & & & & & & & 692 & -25 , & & & & & $-5,284$ \\
\hline 電気蓄熱暖房器 & 103,728 & 358,204 & 50,340 & 59,553 & 387,668 & 4,104 & 78,265 & 327,247 & 36, & 65,161 & 330, & 55 & 35,932 & 253 & 26,147 & 42,971 & 252,443 & $-4,207$ \\
\hline & & & & 22,289 & 93,644 & & & & & & & & 805 & & & & & \\
\hline 灯油ストーブ & 6,774 & 93,476 & 26,3 & 1,731 & 118,579 & 9,2 & 34,911 & 78,167 & & $-3,698$ & & 5,164 & 2,867 & & & $-2,7$ & 80,252 & 3,626 \\
\hline 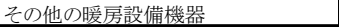 & 32,511 & 167,386 & 34,155 & 3,386 & 188,549 & 12,413 & 48,976 & 139,780 & 30,212 & $-2,795$ & 173,753 & 8,615 & 2,867 & 68,827 & 15,365 & $-2,752$ & 80,252 & 3,626 \\
\hline
\end{tabular}


THERMAL INSULATION AND EQUIPMENT PERFORMANCE

OF A NEWLY BUILT DETACHED HOUSE IN HOKKAIDO

Estimation of primary energy consumption and selection factors for house equipment

\section{Koichi TATEMATSU* , Tomohito HIROTA** , Masahiro TAKAKURA***, Tsukasa TSUKIDATE***, Hirotaka SUZUKI*** and Hirofumi HAYAMA****}

\footnotetext{
* Hokkaido Research Organization Northern Regional Building Research Institute, M. Eng.

** Hokkaido Research Organization Northern Regional Building Research Institute

*** Hokkaido Research Organization Northern Regional Building Research Institute, Dr. Eng. **** Prof., Faculty of Eng., Hokkaido Univ., Dr. Eng.
}

The energy efficiency of housing depends largely on equipment and insulation specifications. In recent years in Hokkaido, housing units with very high thermal insulation performance have been built through various public incentives. Furthermore, there was a spike in fuel prices in 2008, and reductions in electricity consumption were required following the Great East Japan Earthquake of 2011. In 2013, the energy conservation standards for housing were defined by not only thermal insulation performance but also the primary energy consumption of heating, cooling, ventilation, lighting, and hot water supply.

Therefore, the policy framework for energy conservation in housing is currently undergoing rapid change, and is considered to be in a transitional phase. Hence, it is necessary to encourage contractors and householders to select appropriate insulation and equipment specifications, while achieving the complementary policy objectives on energy savings, energy infrastructure, and user needs.

In this study, we investigated the thermal insulation performance and equipment type in a newly built detached house in Hokkaido, and we conducted an estimation of primary energy consumption and considerations of the selection factor of house equipment specifications.

The results were as follows:

(1) The insulation specifications obtained for each section of the insulation system were used to estimate the $U_{\mathrm{A}}$ value with regard to energy conservation standards. In 2012, the $\mathrm{U}_{\mathrm{A}}$ criteria for newly built detached houses were achieved in $89 \%, 90 \%$, and $99 \%$, of cases in areas 1, 2, and 3, respectively. In addition, the average $\mathrm{U}_{\mathrm{A}}$ value shows regional differences, but none compensate for the disparity in heating load due to climatic considerations.

(2) A comparison of the equipment that was installed in 2012 and 2011 demonstrated that although there were significantly fewer installations of electric heaters, the quantity of condensing-type gas instantaneous water heaters greatly increased. Furthermore, the number of air conditioners for room heating was increased, despite the low penetration rate.

(3) We analyzed the relationship between contractor attributes and equipment type. The choice of equipment type shows particularly large variation based on the contractors' location (subprefecture). Central heating is often used in Ishikari, Sorachi, and Shiribeshi. On the other hand, there is widespread use of heat-pump water heaters and room air conditioners for heating in Oshima, Hiyama, Iburi, and Hidaka, whereas electric heating equipment is often used in Kamikawa, Rumoi, Soya, Okhotsk, Tokachi, Kushiro, and Nemuro. It is plausible that these regional characteristics could result from climate, and from the rates and penetration of city gas.

(4) We used a computer program for energy conservation standards to calculate primary energy consumption based on several assumptions. The achievement rates for primary energy consumption criteria were estimated to be $27 \%$, $60 \%$, and $69 \%$ in areas 1, 2, and 3, respectively. These achievement rates are lower than those for $\mathrm{U}_{\mathrm{A}}$. In particular, primary energy consumption increased in area 1, due to the large proportion of homes in which electric heaters were installed.

(5) It was found that the contractor was responsible for selecting equipment specifications. Consequently, because contractors tend to specify newer types of home heating and hot-water equipment, it is important to provide them with appropriate information. 